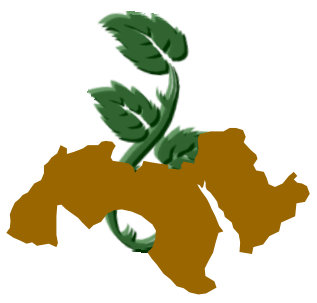

Arab Univ. J. Agric. Sci., Ain Shams Univ., Cairo, 16(2), 481-492, 2008

\title{
INFLUENCE OF GROWING SWEET PEPPER IN COMPACTED RICE STRAW BALES COMPARED WITH NATURAL SOIL, ON INFECTION WITH PATHOGENIC FUNGI AND NEMATODES UNDER GREENHOUSE CONDITIONS
}

\author{
Hanan A. El-Marzoky ${ }^{1}$ and M.A. Abdel-Sattar ${ }^{1}$ \\ 1- Suez Canal University, Faculty of Agriculture, Ismailia, Egypt
}

Keywords: Sweet pepper, Rice straw bales, Tylenchorhynchus sp, Rhizosphere, Black Cloud

\begin{abstract}
Rice straw bales could be used as a growing media for cultivation of vegetable crops instead of soil. The present study, which is considered the first in this respect in Egypt, aimed to evaluate the effect of using rice straw bales as a medium for cultivation of pepper on the disease infection by root pathogens. The cultivation of sweet pepper seedling cv.4408 F1 hybrid on rice straw bales was carried out in two locations: in El-Ismailia Governorate (Abo-Swear and El-Ferdan Districts), under plastic net greenhouse conditions during 7-10 May. 2007. In the first location, Abo-Swear, the disease incidence of root rot, wilt and root knot nematodes in sweet pepper plants grown in rice straw bales reached $1.1,0.85$ and $0.0 \%$ respectively. However, the corresponding figures for sweet pepper plants grown in natural soil under the same conditions were $14.8,21.9$ and $33.2 \%$, respectively. The same trend was observed in the second location El-Ferdan district. Determination of pathogenic nematodes in rice straw bales and natural soil revealed the presence of 80 juvenile (J2) of Meloidogyne spp. and 120 juvenile (J2) of Tylenchorhynchus sp. per $250 \mathrm{~g}$ natural soil. However, the pathogenic nematodes were absent in rice straw bales. Isolation trials from naturally root -rotted and wilted pepper plants grown in natural soil and compacted rice straw bales under plastic net house conditions indicated that both Fusarium oxysporum Schlecht and Rhizoctonia solani kuhn were the most frequent isolated fungi . Other associated fungi belonging to the genera Pythium, Sclerotiom, Trichoderma and Rhizopus showed the lowest frequen-
\end{abstract}

cy. Pathogenicity of the most frequent isolated fungi was proved and showed that pepper plants were attacked by $F$. oxysporum and $R$. solani. Pepper grown in rice bales showed better growth and increased fruit number and weight compared with those grown in natural soil. The $\mathrm{pH}$ around the roots in straw bales ranged from 6.3 to 6.6 which pored to be a slightly acidic substrate. However, the $\mathrm{pH}$ around roots in the natural soil ranged from 7.4 to 8.5 , alkaline soil. So, sowing in rice straw can solve the conditions of alkalinity and salinity in rhizosphere of pepper plants. On the other hand, plants grown in rice bales recorded lower E.C. (1.75 Mmohs $\mathrm{cm}^{-1}$ ) value around the roots compared with the natural soil (2.55 Mmohs $\left.\mathrm{cm}^{-1}\right)$ at the end of the experiment. On the basis of the above results, it could be recommended that using rice straw bales as a growing media in replacing naturally infested soil, can improve the production of pepper under greenhouse conditions for exportation. Also, avoiding the serious environmental air pollution called the "Black Cloud" when disposed about 5 million tons of rice straw every year by burning.

\section{INTRODUCTION}

Pepper (Capsicum annum L.) is one of the vegetables that spreads and grown world wide as a spice and a medicinal crop. There is a great demand of this commodity for foreign markets due to the introduction of many new cultivars under plastic condition. Pepper is subject to be attacked by many diseases in Egypt as well as in many different parts of the world .Soil diseases is one of the most serious problems in protected cultivation. Methyl bromide is the most common way to solve soil - borne diseases. Due to its negative contribu- 
tions to ozone depletion and human health hazards the use of the highly toxic chemical methyl bromide for the control of soil- borne diseases and nematodes in horticultural sector will be banned in Egypt from 2010 onwards. Non - fungicidal and nematicidal applications for fungal diseases and nematodes are one of the major objectives of the plant pathologists all over the world for avoiding hazardous of using chemicals. The use of compacted rice straw bales as an organic growing media was successfully tested as a replacement for methyl bromide and other pesticides for soil treatment in Egypt. The production of rice straw in Egypt annually reached more than 5 million tons which causes serious air pollution when disposed by burning. According to the literature, the lignin, hemicellulose and cellulose contents of rice straw were about $12 \%, 28 \%$ and $60 \%$, respectively (Stahl and Ramadan 2007). These contents are not attractive or favorable for soil fungi and nematodes (Abdel-Sattar, 2005). The raw material of rice straw is very cheaper as the ton of rice straw equal to 60 Egyptian pounds, so it could represent a good substrate for sowing instead of natural infested soil under greenhouse conditions. (Hassan1988) referred to straw bale culture of wheat and barley for growing cucumber and tomato under greenhouses in some Europe and Arab countries. (Choe et al 1991) studied the effect of rice straw application on improvement of soil conditions for growing green pepper under greenhouses. (Salama and Mohmmedien 1996) studied the productivity of sweet pepper grown on agricultural wastes under protected cultivation conditions. (Abdel - Sattar 2004 and 2005) published a new technique for the first time in Egypt for growing cucumber, tomato, pepper, melon and strawberry in greenhouses and open field on compacted rice straw bales, using dissolved fertilizers only. The target of the present work deals with the possible use of rice straw bales as a soilless cultivation medium for improving the productivity of sweet pepper escaping the problems inherent in the natural soils.

\section{MATERIALS AND METHODS}

\section{Fermentation of compacted rice straw bales}

About 200 compacted rice straw bales ( $50 \mathrm{~cm}$ height $\times 70 \mathrm{~cm}$ width $\times 120 \mathrm{~cm}$ length) obtained from commercial suppliers, were arranged to form two rows in each greenhouse for sweet pepper cultivation. Drip irrigation lines were extended on top of the rice straw bales with two drip lines on each row installed at a distance of $50 \mathrm{~cm}$. The straw bales were first irrigated for six hours for washing soil particles, and then the dissolved fertilizers ammonium and potassium sulphate and phosphoric acid $85 \%$ were injected daily through the irrigation system, 10-12 days before planting for rice straw fermentation.

\section{Transplanting}

Red colored sweet pepper seedlings with three or four true leaves were transplanted 7-10 May 2007 in the fermented rice straw bales. The distances between seedlings were $50 \mathrm{~cm}$ apart ( plant density was 2.3 plant per square meter ) and the plants were watered by the drip irrigation system until the end of the season .

\section{Fertilization}

The nutrition management in rice straw bales culture was similar as the sandy soil culture. The exception to the sandy soil culture was the higher use of nitrogen as soon as the rooting process in the straw bales started (C: N ratio 98:2, Salama and Mohammedien, 1996). The fertilization scheme with $\mathrm{N}, \mathrm{P}, \mathrm{K}$ and $\mathrm{Mg}$ depending on the physiological status of the growing plants during different stages of development. The daily doses of different dissolved fertilizers were injected into the drip irrigation water.

\section{Disease assessment}

Incidence of root rot, basal stem rot, wilt diseases as well as root knot nematodes on and in roots of red sweet pepper plants at different stages grown in rice straw bales as compared with natural soil under greenhouse conditions were recorded.

\section{Isolation and identification of the associated fungi}

Sweet pepper roots showing rot disease and wilt symptom were used for isolation of the pathogenic fungi. Infected roots were first washed with running tap water, dried between filter papers, then surface sterilized with sodium hypochlorite solution (2\%) for two minutes. Internal diseased portions were transferred onto PDA medium and incubated at $25^{\circ} \mathrm{C}$ for 5-7 days. Counts of fungal colonies from tested root parts were recorded. Identification of the isolated fungi was carried out according to their keys Booth (1997) and Moubasher (1993) and kindly confirmed by Assiut University Mycological Centre. 


\section{Pathogenicity tests}

The high frequencies of isolated fungi were tested for their pathogenic capabilities on $4408 \mathrm{~F} 1$ hybrid sweet pepper cultivar during 2007 season under greenhouse conditions at Faculty of Agriculture Farm, Suez Canal University. Sterilized pots $20 \mathrm{~cm}$ in diameter were potted with autoclaved light loam soil, and infested with inocula at the rate of $5 \%$, except in the case of Rhizoctonia solani which was at the rate of $2 \%$. Inocula were prepared by growing the isolates on autoclaved barley grain medium and incubated at $28^{\circ} \mathrm{C}$ for 3 weeks. Five surface sterilized pepper seeds were sown in each pot, one week after soil inoculation. Pots containing non-infested soil mixed with sterilized barley medium were used as control. The pots were irrigated when necessary and examined daily. The percentage of pre and post emergence damping off was recorded and re-isolation of the pathogenic fungal isolates from infected plants was carried out according to Koch postulates.

\section{Vegetative growth characters}

Some important growth parameters of red sweet pepper plants at different stages after sowing $30,45,60$ and 75 days such as stem length (cm), number of leaves / plant, fresh weight /plant (g) as well as fruit yield as affecting by sowing in rice straw bales under greenhouse conditions were continuously recorded.

\section{Total soluble solids}

Few drops of the filtrated juice of red sweet pepper as affected by sowing in rice straw bales were placed on the plate of a hand refractmeter. The percentage of total soluble solids was determined in both fruits grown on rice straw bales and natural sandy soil.

\section{Vitamin C}

Vitamin C .(ascorbic acid) content was determined in both red sweet pepper fruits grown on rice straw bales compared with those grown in natural soil according to Anonymous (1990).

Determination of temperature, electric conductivity (EC) and $\mathrm{pH}$ in rhizosphere of pepper plants

Temperature, degrees in the rhizosphere of red sweet pepper plants, electric conductivity (EC) in nutrient solution and around the root system were determined in rice straw bales compared with check plot cultivated on natural soil.

\section{Statistical analysis}

The collected data were statistically analyzed using two factors completely Randomized block Design. Treatments were compared at 0.05 and 0.01 level of probability LSD (Steel and Torrie 1960).

\section{RESULTS AND DISCUSSION}

\section{Occurrence of root rots, wilt disease and root} knot nematodes

The occurrence of root rot, wilt accompanied with basal stem rot and root knot nematodes in sweet pepper plants grown in rice straw bales reached $1.1,0.85$, and $0.0 \%$, respectively. However, the corresponding figures for sweet pepper plants grown in natural soil under the same conditions were $14.8,21.9$, and $33.2 \%$, respectively. The infection with root rot and wilt of sweet pepper grown in rice straw bales might be attributed to contaminated rice straw with soil particles or through contaminated irrigation water. Determination of pathogenic and free living nematodes (non - pathogenic) in rice straw bales and natural soil revealed the presence of 80 juvenile (J2) of Meloidogyne spp. and 120 juvenile (J2) of Tylenchorhynchus sp. per $250 \mathrm{~g}$ natural soil. Injuries caused by nematode infections increases the susceptibility of the plant to invasion with wilt fungus ( $F$. oxysporum), which can enter the basal stem tissues through epidermal wounds and develop a localized rot. However, the pathogenic nematodes were absent in rice straw bales (Fig.1). In the same time, free living nematodes (non pathogenic) were recorded in both natural soil and rice straw bales. It is also clear from data presented in (Fig. 1) that, the diseases percentages in El-Ferdan was higher than in Aboswear.

\section{Isolation and identification of the associated fungi}

Isolation trials from naturally root - rotted and wilted pepper plants grown in natural soil and compacted rice straw bales under plastic net house conditions indicated that both Fusarium oxysporum and Rhizoctonia solani were the most frequent isolated fungi .Other associated fungi (Pythium sp., Sclerotium sp., Trichoderma spp. and Rhizopus sp. ) showed the lowest frequency. 
Abo- Swear District
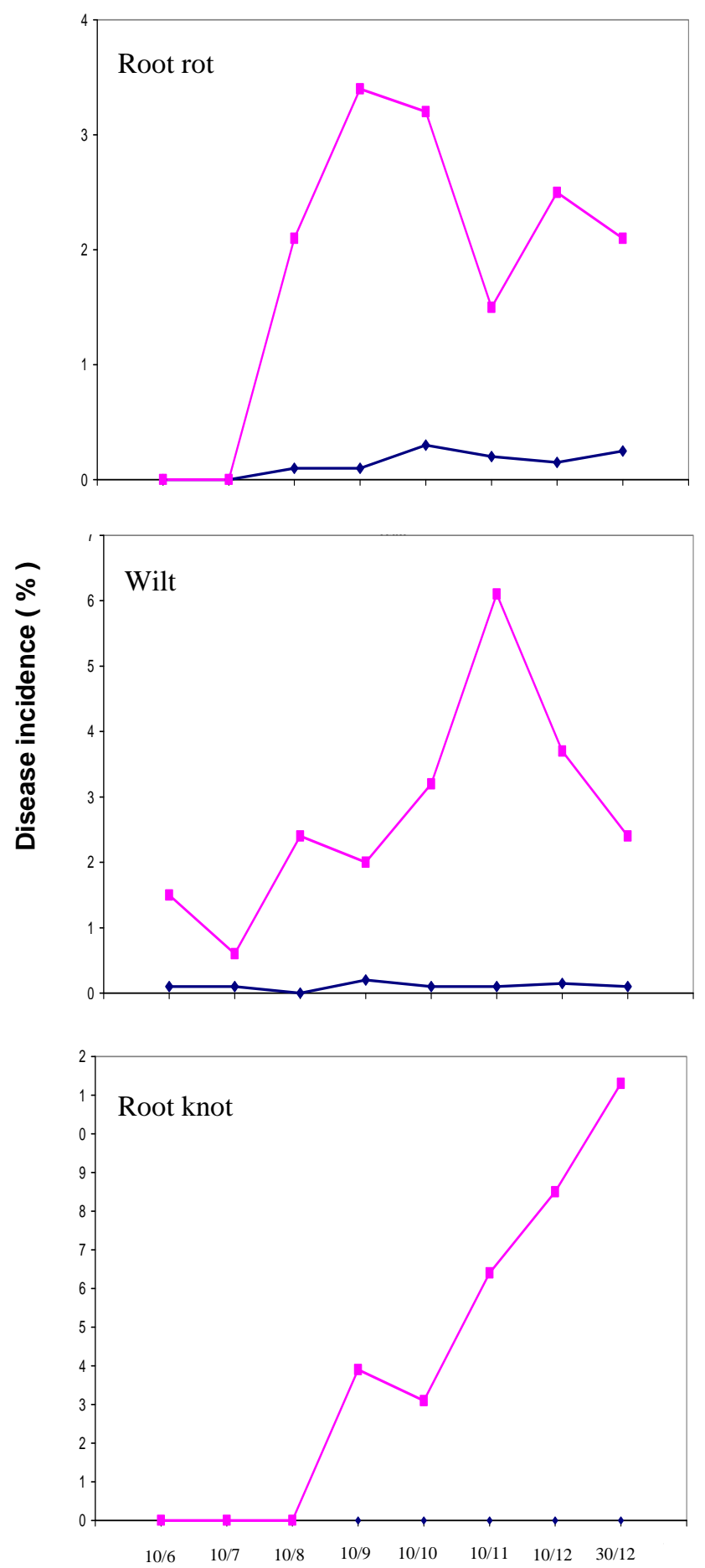

El-Ferdan District
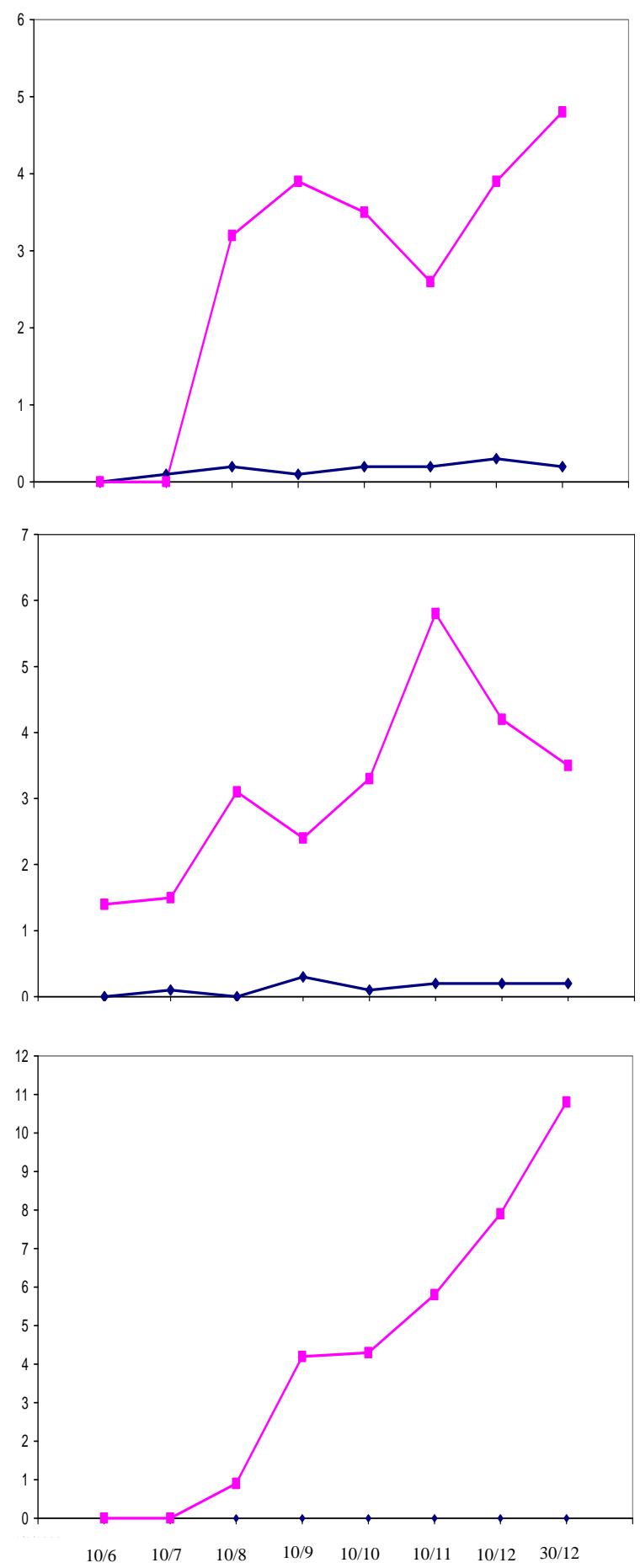

- Rice straw $\rightarrow-$ Soil

- Rice straw -I-Soil

Date of test

Fig.1. Incidence of root rot, wilt and root knot nematode on/in roots of sweet pepper at different stages as affected by sowing in rice straw bales under greenhouse conditions during season 2007 
According to morphological characters and the specific keys the Fusarium isolates isolated from pepper plants were identified as Fusarium oxysporum Schlecht and Rhizoctonia isolates obtained from pepper plants showed root rot were identified as Rhizoctonia solani kuhn (Fig. 2-B ).

Rhizoctonia root rot caused by Rhizoctonia solani generally affects seedlings. But the fungus can also infect adult pepper plants and induce root rot, which leads to wilting and death of pepper plants. It is known that Rhizoctonia solani persists in soils and organic debris.

Symptoms of sweet pepper wilt disease caused by F. oxysporum (Fig. 3-A) include leaf choruses, vascular discoloration and wilting pepper plants were recorded.

Pathogenicity test with the most frequent isolated fungi (Table, 1)

Pathogenicity test revealed that Rhizoctonia solani recorded the higher percent of pre emergence damping off. However, F. oxysporum showed the highest percent of post emergence damping off. It's also clear that mortality of pepper plants were higher with $R$. solani compared with $F$. oxysporum. Generally pathogenicity test proved that both fungi are pathogenic to sweet pepper causing pre and post emergence damping off, root rot and wilt of adult plant.

\section{Vegetative characters of sweet pepper plants} as affected by sowing in rice straw bales

Red sweet pepper plants grown in rice straw bales under plastic net greenhouse conditions in two locations showed better growth (Fig. 4) and an increase in root and shoot systems, weight and length/ plant compared with those in the control plot (Table 2). Number of fruits per plant was sig- nificantly enhanced by growing on rice straw bales which had great effect on root growth, nutrients and water uptake. These results are agreed with those reported by Wilson (1986); Marchesinia et al (1988) and Abdel - Sattar (2005). The significant increase in the yield might be due to the increase of fruit number which turns due to an increase in flower production, fruit set or both. It has been reported by Salama and Mohammedien (1996) that artificial media (rice straw covered with legume wastes peas and beans in layers, gave the highest yield and improved fruit characteristics of sweet pepper. Choe et al (1991) studied the effect of rice straw application on improvement of soil conditions for growing green pepper under greenhouses. They reported that, the change in microbial flora around the root zone was better with rice straw applications and $\mathrm{Co} 2$ production was also increased with more straw application. It was also found that, plants grown in rice straw bales gave the higher values of total soluble solids and acidity $(\mathrm{pH})$ in juice of pepper fruits as compared with the control.

It seems that rice straw media had positive effect on root length and weight due to better absorption of water and nutrients by roots. On the other had, no clear and non significant differences were observed between leave dry weight, ascorbic acid content in red pepper fruits, fruit length and stem length in pepper plants grown either in rice straw bales or natural infested soil.

Degrees of $\mathrm{pH}$ and electric conductivity (EC) around roots of sweet pepper plants as affected by sowing in rice straw bales

Data in (Table 3) show the degrees of $\mathrm{pH}$ and EC around roots of sweet pepper plants as affected by sowing in rice straw bales compared with natural soil in both the two locations. The $\mathrm{pH}$

Table 1. Pathogenicity test with the most frequent isolated fungi $F$. oxysporum and $R$. solani the causal pathogens of damping off and root rots in $4408 \mathrm{~F}$ I, hybrid pepper plants

\begin{tabular}{|l|c|c|c|c|}
\hline \multirow{2}{*}{ Inoculated fungi } & \multicolumn{3}{|c|}{ Damping off and root rot \% } \\
\cline { 2 - 5 } & $\begin{array}{c}\text { Pre emergence damping } \\
\text { off }\end{array}$ & $\begin{array}{c}\text { Post emergence damping } \\
\text { off }\end{array}$ & Mortality & Survival \\
\hline Fusarium oxysporum & 10 & 50 & 60 & 40 \\
Rhizoctonia solani & 25 & 40 & 65 & 35 \\
Control & 0.0 & 0.0 & 00 & 100 \\
\hline
\end{tabular}



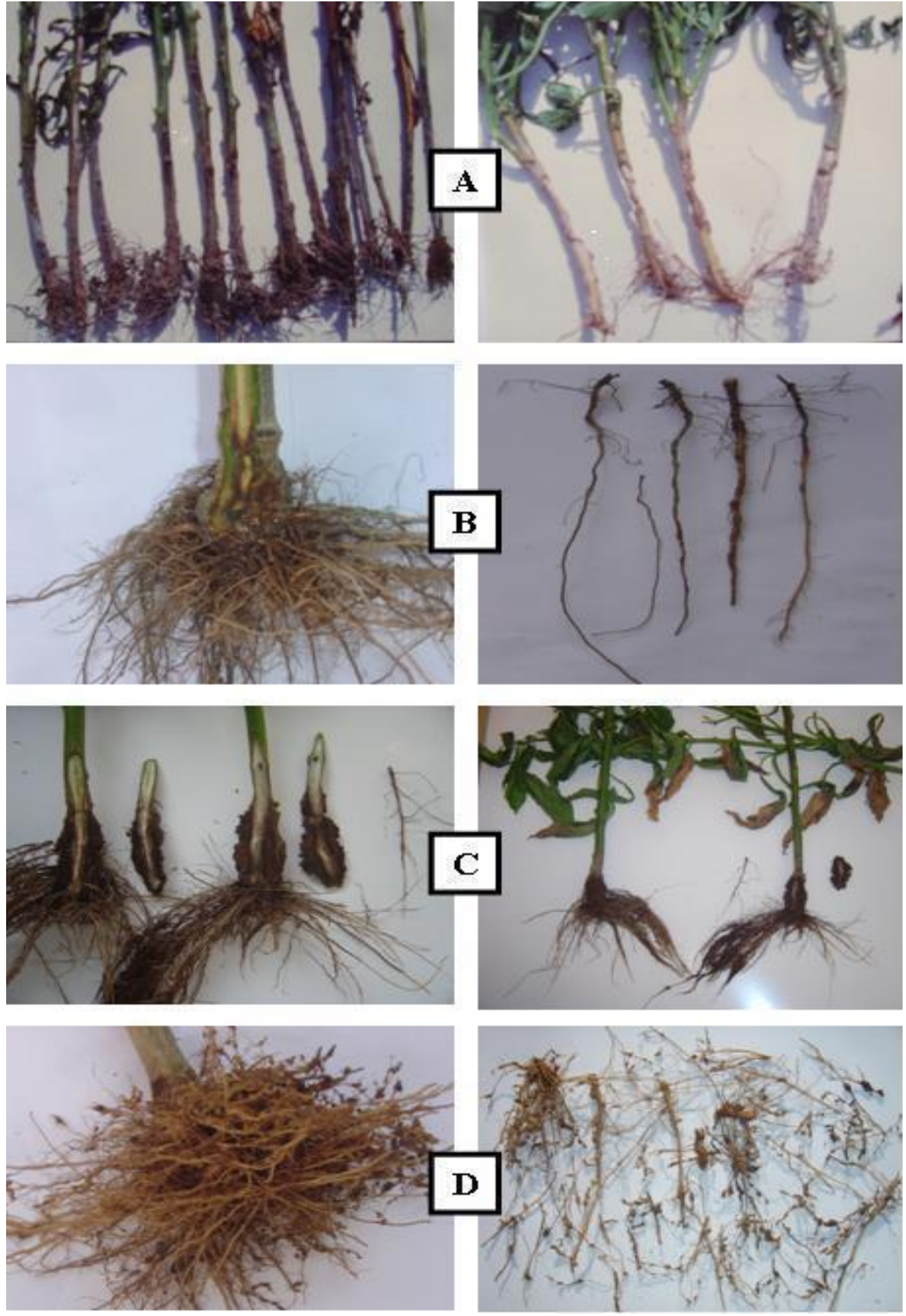

Fig. 2. Showing different symptoms of pepper plant infected with root and basal stem rot from which Pythium spp. (A), R. solani (B), F. oxysporum and R. solani (C) and Meloidogyne spp. (D )were isolated 

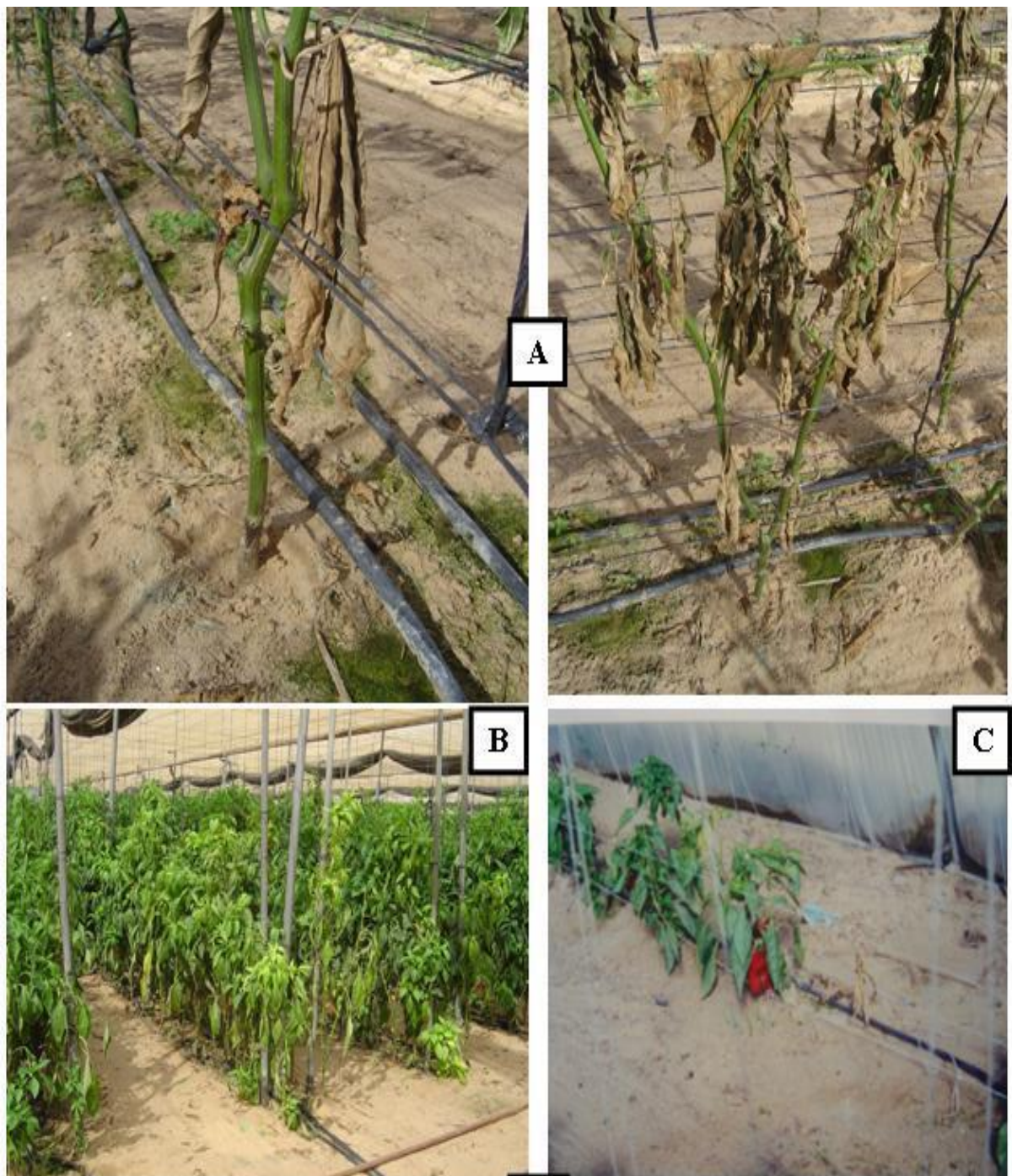

$\mathrm{C}$

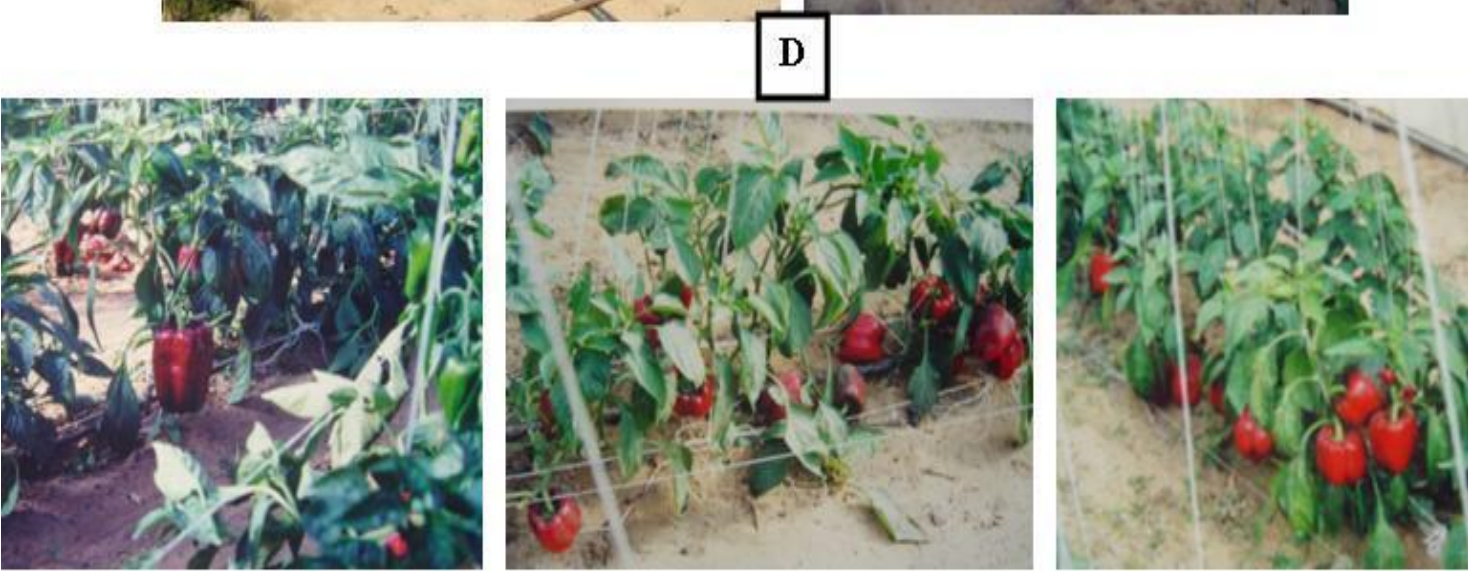

Fig. 3. Symptoms of pepper wilted plants at Abo-Swear greenhouses (A), symptoms of nematodes, showing the yellow leaves in the top (B), Pre and post emergence damping off El-Ferdan greenhouse (C) and Healthy pepper plants grown in natural soil (D). 

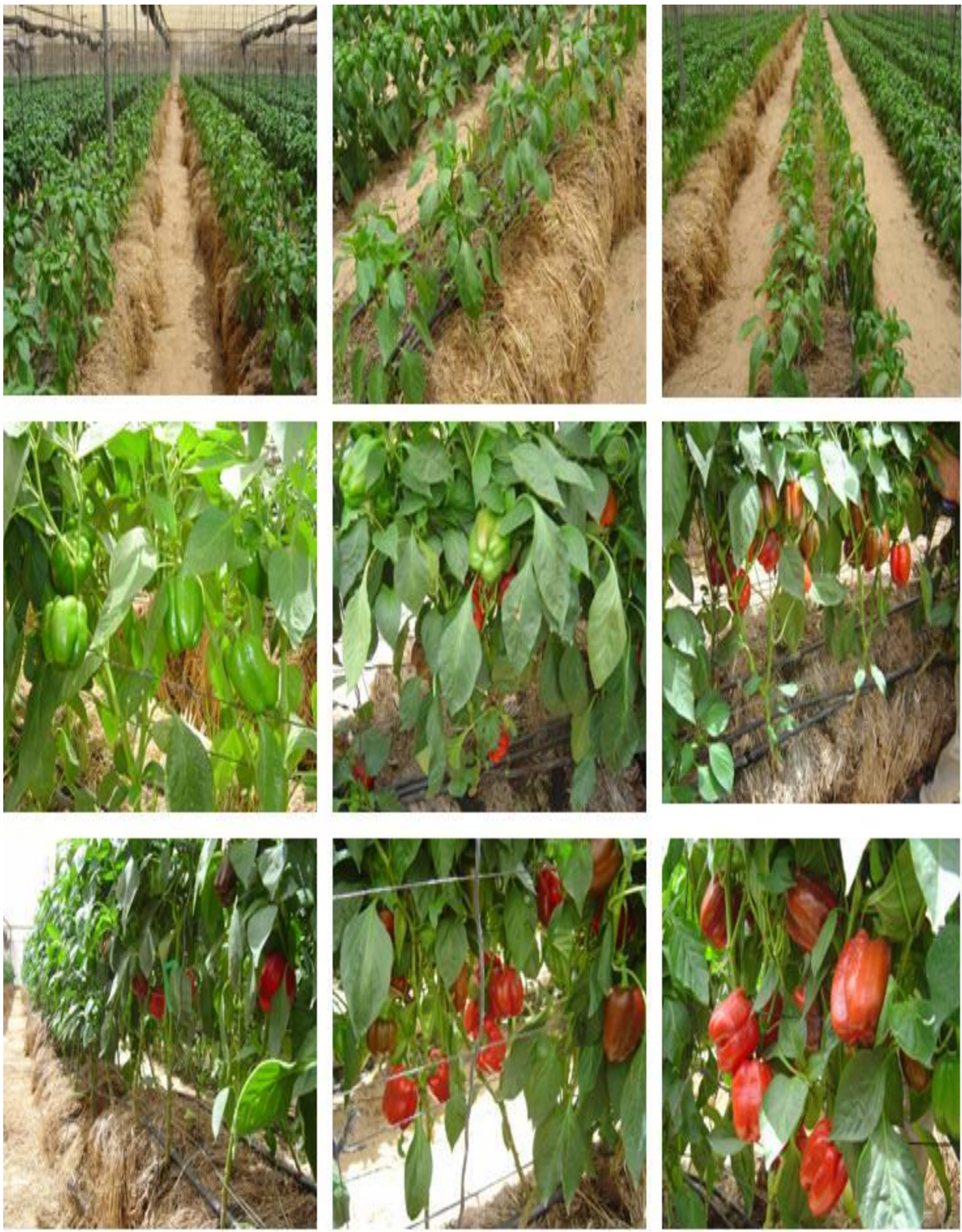

Fig. 4. Red sweet pepper plants grown in compacted rice straw bales at different stages of development showing the healthy plant and a good quantity and quality of pepper fruit (AboSwear plastic nets). 
Table 2. Some vegetative growth characters of red pepper plants as affected by sowing in rice straw bales under plastic net greenhouse conditions

\begin{tabular}{|c|c|c|c|c|c|c|c|}
\hline \multirow{3}{*}{ Characteristics } & \multicolumn{7}{|c|}{ Treatments } \\
\hline & \multicolumn{3}{|c|}{$\begin{array}{l}\text { Sowing on rice straw } \\
\text { bales }\end{array}$} & \multicolumn{3}{|c|}{ Sowing in natural soils } & \multirow{2}{*}{$\begin{array}{l}\text { L.S.D } \\
5 \%\end{array}$} \\
\hline & $\begin{array}{l}\text { Abo- } \\
\text { Swear }\end{array}$ & $\begin{array}{c}\text { El- } \\
\text { Ferdan }\end{array}$ & Mean & $\begin{array}{l}\text { Abo- } \\
\text { Swear }\end{array}$ & $\begin{array}{c}\text { El- } \\
\text { Ferdan }\end{array}$ & Mean & \\
\hline No. of fruits /Plant & 36.3 & 83.8 & 37.5 & 31.0 & 33.2 & 32.1 & .15 \\
\hline Fruit production weight / plant $(\mathrm{kg})$ & 7.3 & 7.8 & 7.5 & 6.2 & 6.6 & 6.4 & 0.11 \\
\hline Average of single fruit weight $(\mathrm{g})$ & 215 & 230 & 222.5 & 225 & 220 & 222.5 & $\mathrm{~ns}^{*}$ \\
\hline Fruit diameter $(\mathrm{cm})$ & 10.0 & 11.2 & 10.6 & 10.3 & 10.5 & 10.4 & 0.19 \\
\hline Fruit length $(\mathrm{cm})$ & 10.1 & 12.0 & 11.1 & 10.5 & 11.5 & 11.0 & 0.21 \\
\hline Fruit dry weight(g) & 12.6 & 12.7 & 12.7 & 13 & 12.9 & 12.97 & 0.11 \\
\hline Stem dry weight (g) & 25.5 & 25.9 & 25.7 & 22.7 & 23.1 & 22.9 & 0.1 \\
\hline Leave dry weight $(\mathrm{g})$ & 27.6 & 28.1 & 27.8 & 27.8 & 28.2 & 28.01 & 0.21 \\
\hline Ascorbic acid content in red pepper fruits( $\mathrm{Mg})$ & 156.2 & 166.4 & 161.3 & 157.1 & 166.6 & 161.84 & 7.1 \\
\hline Total soluble solids & 8 & 7 & 7.5 & 6 & 6.5 & 6.25 & 0.14 \\
\hline $\mathrm{pH}$ in juice of red pepper fruits (\%) & 5.1 & 5.1 & 5.1 & 4.9 & 4.9 & 4.9 & 0.01 \\
\hline Root length $(\mathrm{cm})$ & 67 & 69 & 68 & 50 & 50 & 50 & 1.3 \\
\hline Root weight (g) & 240 & 255 & 247.5 & 125 & 160 & 142.5 & 3.9 \\
\hline Shoot system weight & 500 & 550 & 525 & 490 & 530 & 510 & 14.4 \\
\hline Stem length $(\mathrm{cm})$ & 220 & 230 & 225 & 225 & 230 & 227.5 & 6.3 \\
\hline
\end{tabular}

${ }^{*}$ ns $=$ non significant

Table 3. Degrees of $\mathrm{pH}$ and electric conductivity $\left(E C=M m o h s \mathbf{c m}^{-1}\right)$ around roots of sweet pepper plants as affected by sowing in rice straw bales under greenhouse conditions as compared with natural soil (mean of the two locations Abo -Swear and El-Ferdan)

\begin{tabular}{|c|c|c|c|c|}
\hline Date of test & $\begin{array}{c}\text { pH around roots } \\
\text { in straw bales }\end{array}$ & $\begin{array}{c}\text { pH around roots } \\
\text { in natural soil }\end{array}$ & $\begin{array}{c}\text { E.C. (Mmohs } \mathbf{~ c m}^{-1} \text { ) } \\
\text { around roots in } \\
\text { straw bales }\end{array}$ & $\begin{array}{c}\text { E.C. (Mmohs } \mathbf{~ c m}^{-1} \text { ) } \\
\text { around roots in } \\
\text { natural soil }\end{array}$ \\
\hline $10 / 6 / 2007$ & 6.3 & 7.4 & 1.16 & 1.20 \\
$10 / 7 / 2007$ & 6.4 & 7.5 & 1.17 & 1.30 \\
$10 / 8 / 2007$ & 6.5 & 7.7 & 1.37 & 2.00 \\
$10 / 9 / 2007$ & 6.5 & 7.8 & 1.59 & 2.95 \\
$10 / 10 / 2007$ & 6.6 & 7.5 & 2.06 & 2.97 \\
$10 / 11 / 2007$ & 6.5 & 7.8 & 2.17 & 3.09 \\
$10 / 12 / 2007$ & 6.4 & 8.1 & 2.23 & 3.16 \\
$30 / 12 / 2007$ & 6.5 & 8.5 & 2.25 & 3.73 \\
\hline Mean & 6.46 & 7.78 & 1.75 & 2.55 \\
\hline
\end{tabular}


around the root in straw bales ranged between 6.3 to 6.6 which indicate to be a slightly acidic substrate. However, the $\mathrm{pH}$ around the roots of pepper plants grown in natural soil under greenhouse conditions ranged between 7.4 to 8.5 which indicate that it is alkaline soil. It is known that, the acidity of the soil played a role in the growth and the development of cultivated plants. The $\mathrm{pH}$ 6.3-6.6 is favorable for dissolving the insoluble salts. So, sowing in rice straw bales $(\mathrm{pH}$ 6.3-6.6) instead of natural soil ( $\mathrm{pH} 7.4-8.5)$ can solve the conditions of alkalinity and salinity in rhizosphere of pepper plants. Piccha (2001) reported that, salt accumulation can cause considerable economic loss to growers and accumulation of salts in natural soil can negatively affect the development of young plants.

On the other hand, plants grown in rice straw bales recorded lower E.C value around the roots compared with the control (natural soil) during different stages of pepper development. In the natural soil, EC value increased with increasing the plant age. There are considerable and significant differences between EC around pepper roots grown in rice straw and natural soil at the end of the experiment. The E.C. value reached 2.55 Mmohs $\mathrm{cm}^{-1}$ around pepper roots in natural soil compared with $1.75 \mathrm{Mmohs} \mathrm{cm}^{-1}$ in rice straw bales (Table 3). Accumulation of excessive amounts of nutrients take place in natural soil more than in rice straw bales. The results agreed with Ruizernaars (1984) who reported that cucumber plant growth was enhanced by the lower E.C. value .On the contrary, Jovicich and Cantliffe (2004 ) reported that pepper are relatively sensitive to moderate and high level of salts in the growing media solution. They also reported that, symptoms of basal stem epidermal injuries have been observed in both soil and soilless cultivated pepper plants where excessive amount of salts (salts from the soil, irrigation water or fertilizers) concentrated around the base of the stem. Deposes of salts on basal stem epidermal tissues contribute to localized injuries, which predispose the plant to an infection by the pathogens.

Generally, it can be concluded that, plants grown on rice straw bales had vigorous vegetative growth, greater total yield beside improved fruit quality than those grown in naturally infested soil. It seems that rice straw bales had merits on aeration, root growth, nutrients and water uptake and consequently on sweet pepper plant growth and yield quantity and quality. Also, it could be recommended that using compacted rice straw bales as a growing media in replacing naturally infested soil can control soil borne diseases as well as pathogenic nematodes without using pesticides.

\section{REFERENCES}

Abdel-Sattar, M.A. (2004). Using compacted rice straw bales for growing some vegetables and fruits Egypt. Min. Agric., Tech. Bull. 2, 72 pp. (in Arabic).

Abdel-Sattar, M.A. (2005). Using compacted rice straw bales, as a growing media instead of naturally infested soil for improving cucumber production under greenhouse conditions in Egypt. The $6^{\text {th }}$ Arabian Conference for Horticulture, Ismailia, Egypt. pp. 265-278.

Anonymous. (1990). Official Methods of Analysis, $15^{\text {th }}$ Ed. Association of Official Analytical Chemists, Inc., Washington D.C

Booth, C. (1977). Fusarium Laboratory Guide to the Identification of the Major species, $58 \mathrm{pp}$. Commonwealth Mycological Institute, Kew, Surrey, UK.

Choe, S.; K.H. Kank; Y.C. Um and Y.H. Choe (1991). Effect of rice straw application on improvement of soil circumstances for growing green pepper under vinyl greenhouses. Hort. Exp. Station, 20, Kangdong-don, Kango-gu, Busan City, Korea Republic, (C.F. Hort. Abst. 63: 1; 1993).

Hassan, A.A. (1988). Technology of Protected Cultivation (Greenhouses). 253 pp. El - Dar - Al -Arabia for Publishing and Distribution, Cairo (in Arabic)

Jovicich, E. and D.J. Cantliffe.2004 .Salts deposited on the lower stem of bell pepper contributes to a basal stem disorder in soilless, greenhouse grown plants. Hort. Science 39(1): 36-39.

Marchesinia, A.; L. Allievi; E. Comotti and A. Ferrori. (1988). Long-term effect of quality - compost treatment on soil. Plant and Soil, 106: 253 261.

Moubasher, A.H. (1993). Soil fungi in Qatar and Other Arabic Countries. 566 pp. The Scientific and Applies Research Centre, University of,Doha . Qatar.

Piccha, D. (2001). Soil Salinity Management for Strawberry. Agricultural Technology Utilization \&Transfer Project, Publication No.138, USAID Project No. 263- 0240, 14 pp.

Ruizernaars, Y. (1979). Autumn cucumber in the energy saving glasshouse in 1984. Herfistkommers in de energiekas in 1984(2). Groenten en Fruit (1985) 41(10):30-31, Naaldwijk, Netherlands. (C.F. Hort. Abst., 57: 6382, 1987). 
Salama, G.M. and S.A. Mohammedien (1996). A study on productivity of sweet pepper grown on agricultural wastes under protected cultivation conditions. Egypt. J. Hort. 23(1): 1-10.

Stahl, R. and A.B. Ramadan (2007). Fuels and chemicals from rice straw in Egypt. Forschungszentrum Karisruhe $\mathrm{GmbH}$, Karisruhe, Wissenschaftliche berichte , FZKA 7361, 70 pp.
Steel, R.G. and T.H. Torrie (1960). Principle and Procedures of Statistics, 481 pp. Mc Graw Hill Book Co.Inc., New York.

Wilson, G.C.S. (1986). Tomato production in different growing media .The west of Scotland, Agricultural College Auchinenuve. Agr. Scotland. Acta Horticulture, 178:115-120. 